\title{
MERCURY AND METHYLMERCURY IN HAIR OF SELECTED GROUPS OF CZECH POPULATION
}

\author{
Kateřina Wranová1,3, Mája Čejchanová1, Věra Spěváčková1, Vlasta Korunová2, Miloslav Vobecký2, \\ Václav Spěváček ${ }^{4}$ \\ ${ }^{1}$ National Institute of Public Health, Prague, Czech Republic \\ ${ }^{2}$ Institute of Analytical Chemistry, Academy of Sciences of the Czech Republic, Prague, Czech Republic \\ ${ }^{3}$ Charles University Prague, Faculty of Science, Department of Analytical Chemistry, Prague, Czech Republic \\ ${ }^{4}$ Technical University Prague, Faculty of Nuclear Science and Engineering, Prague, Czech Republic
}

\begin{abstract}
SUMMARY
As the concentration of methylmercury (MeHg) in the environment is insignificant, hair can be used as a suitable matrix to estimate endogenous MeHg exposure. A validated analytical method with AMA 254 spectrometer was used for the determination of inorganic mercury and methylmercury species in the hair of dentists, workers in fish industry and professionally non-exposed adults. ANOVA and QC Expert software was used for statistical evaluation. The number of amalgam fillings in oral cavity, consumption of fish, gender, smoking habits and age of the subjects were taken into account. A significantly higher level of inorganic bound mercury $\left(\mathrm{Hg}_{\mathrm{in}}\right)$ was found in the hair of dentists. The number of amalgam fillings had a slightly significant effect on $\mathrm{Hg}_{\mathrm{in}}$; fish consumption had a significant influence on $\mathrm{MeHg}$ and slightly also on $\mathrm{Hg}_{\mathrm{in}}$. Other parameters were not significant.
\end{abstract}

Key words: methylmercury, hair, sampling, contamination, storage, population groups

Address for correspondence: M. Čejchanová, National Institute of Public Health, Šrobárova 48, 10042 Prague 10, Czech Republic. E-mail: mcejch@szu.cz

\section{INTRODUCTION}

From the toxicological point of view, mercury belongs to the very toxic elements for humans. Most important species for living organisms are elemental form, divalent mercury and organic mercury compounds. Health risks of exposure to mercury and its compounds are well described in literature (1-9). From these publications it follows that urine, blood and hair are the most used biomarkers of mercury body burden (with some limitations). Urine is considered to be the best indicator of body burden from long-term exposure to elemental and inorganic mercury $\left(\mathrm{Hg}_{\mathrm{in}}\right)$, blood is a good biomarker of short-term exposures. The use of hair analysis in environmental medicine is discussed in some reports $(10,11)$ and in materials of Agency for toxic substances and disease registry (12).

From these publications we can summarized that hair is well suited as a biomarker for the methylmercury $(\mathrm{MeHg})$ endogenous exposure. Very detailed overviews concerning hair studies are done in monographs $(13,14)$. Many papers have been devoted to the hair mercury and fish consumption, to the problems connected with amalgam fillings, professional exposure in dentist's surgeries and/or combination of various factors (15-26).

For the Czech population, more data are available on total mercury $\left(\mathrm{Hg}_{\mathrm{tot}}\right)$ in blood, urine and serum than in hair. Review of trace elements in human including mercury in blood, serum and urine was published in (27-29), for mercury in hair only few data are done (30-33). Results of a large project "The Environmental Health Monitoring System in the Czech Republic", which include also human biomonitoring, showed that the total mercury concentration in blood and urine (adults and children) and hair (only children) was low during the whole study and did not exceed values representing health problems. For example, in 2007 (adults) and 2006 (children) medians of total mercury concentration were as follows: blood adults male $0.85 \mu \mathrm{g} . \mathrm{l}^{-1}$, female $0.89 \mu \mathrm{g} . \mathrm{l}^{-1}$; urine adults $1.1 \mu \mathrm{g} . \mathrm{g}^{-1}$ of creatinine; children blood $0.45 \mu \mathrm{g} . \mathrm{l}^{-1}$; children urine $0.3 \mu \mathrm{g} . \mathrm{g}^{-1}$ of creatinine; children hair $0.13 \mu \mathrm{g} . \mathrm{g}^{-1}$. These results were lower than limits defined by the German Committee for Human Biological Monitoring (HBM I) - blood $5 \mu \mathrm{g} . \mathrm{l}^{-1}$, urine $5 \mu \mathrm{g} \cdot \mathrm{g}^{-1}$ of creatinine (34) and with the U.S. EPA limit for hair $-1 \mu \mathrm{g} . \mathrm{g}^{-1}$, and did not represent health risks for general Czech population. As the average concentration of mercury found in air was about $0.001 \mu \mathrm{g} . \mathrm{m}^{-3}$ and median of mercury concentration in drinking water $0.1 \mu \mathrm{g} . \mathrm{l}^{-1}(35)$, the main source of the mercury intake of non-exposed population is food consumption. An average exposure to the mercury in diet was $0.08 \mu \mathrm{g} \mathrm{Hg}$ per kg b.w. and week, i.e. about $5 \%$ of the provisional tolerable weekly intake (PTWI), defined by Joint FAO/WHO Expert Committee on Food Additives (JECFA) for $\mathrm{MeHg}$ (36).

In connection with changes of the dietary habits of Czech population (higher frequency of fish consumption in the last years), the Scientific Committee for Foodstuffs in the Czech Republic decided in 2004 that a study of body burden of methylmercury is necessary even that the fish consumption is still low in comparison with seaboard states: $<5 \mathrm{~kg}$ per reference man per year with seafood accounting for $63 \%$ of this amount $(1,36)$. Results from this study will serve as a starting point for future biomonitoring studies. For this purpose we used a rapid and very simple validated method described previously $(31,37)$. 


\section{MATERIAL AND METHODS}

\section{Instrumentation}

All measurements were performed on a single-purpose spectrometer AMA 254 (Altec Prague Ltd. Czech Republic) by cold vapour atomic absorption spectroscopy (CVAAS) technique with a previous combustion of the sample in oxygen atmosphere and amalgamation preconcentration (38).

\section{Reagents, Vessels}

Demineralised water (Millipore), 18.2 $\mathrm{M} \Omega . \mathrm{cm}^{-1}$, nitric acid (Suprapur grade, Merck, Germany), concentrated and 2 mol.1-1 hydrochloric acid (Suprapur grade, Merck), standard solution for AAS Hg 1.000 \pm 0.002 g. $1^{-1}$ (Merck), methylmercury chloride (analytical standard, Riedel de Haen, Germany), oxygen of medical purity (Linde, Prague, Czech Republic).

Working standards were prepared from the standard solution and stabilized by $1 \% \mathrm{v} / \mathrm{v} \mathrm{HNO}_{3}$ and $0.01 \% \mathrm{w} / \mathrm{v}$ potassium dichromate (reagent grade, Lachema, Czech Republic).

Reference materials of hair were CRM GBW 07601 (total mercury) and IAEA 085 (methylmercury).

Before use, glass vessels and tubes were washed as described in (31).

\section{Analytical Method for Mercury Determination}

To determine the $\mathrm{Hg}_{\mathrm{tot}}, \mathrm{Hg}_{\text {in }}$ and $\mathrm{MeHg}$ levels among various groups, scalp hair samples (about $0.2 \mathrm{~g}$ ) from the occipital area were cut on about $4 \mathrm{~mm}$ pieces, homogenized, washed by the procedure, recommended by WHO/IAEA (acetone, 3 times demineralized water, acetone) and dried at about $50{ }^{\circ} \mathrm{C}$ in drying oven.

Total mercury concentration was determined directly without mineralization: about $10 \mathrm{mg}$ of the sample was weighed into the boat of AMA 254 analyser, dried, combusted, and decomposed in a stream of oxygen on a catalytic column. After quantitative mercury trapping on the surface of gold amalgamator, the mercury was completely evaporated at $900{ }^{\circ} \mathrm{C}$ into the optical cell and measured at $253.7 \mathrm{~nm}$.

Methylmercury was leached from the subsample of hair by hydrochloric acid $\left(2 \mathrm{~mol} . \mathrm{l}^{-1}, \mathrm{v} / \mathrm{w}=40 \mathrm{ml} / \mathrm{g}\right)$ for $4 \mathrm{~h}$. After centrifugation, $100 \mu \mathrm{l}$ of leachate was pipetted into AMA 254 boat and measured by the same way as total mercury.

The content of inorganic bound mercury was calculated as a difference between Hgtotal and $\mathrm{MeHg}$.

\section{RESULTS}

\section{Characteristic of Population Groups}

Groups of dentists, workers in fish industry and professionally non-exposed adults (altogether 60 persons) were included in our study. Filled-in questionnaires included the number of amalgam fillings, frequency of fish consumption, gender, age, smoking habits and informed consent. Descriptive data are shown in Table 1.
Table 1. Characteristic of the population groups (\%)

\begin{tabular}{|l|c|c|}
\hline Age (mean) & & 44 years (range 17-77) \\
\hline \multirow{3}{*}{ Area } & & $\%$ \\
\hline \multirow{3}{*}{ Gender } & town & 77 \\
\hline \multirow{4}{*}{ Profession } & region & 23 \\
\cline { 2 - 3 } & male & 28 \\
\cline { 2 - 3 } & professionally non-exposed & 72 \\
\cline { 2 - 3 } & fresh water industry & 35 \\
\hline \multirow{3}{*}{$\begin{array}{l}\text { Smoking } \\
\text { habits }\end{array}$} & non-smoker & 48 \\
\hline \multirow{4}{*}{$\begin{array}{l}\text { Fish } \\
\text { consumption }\end{array}$} & smoker & 17 \\
\cline { 2 - 3 } & never or exceptionally & 92 \\
\cline { 2 - 3 } & $1-2$ per month & 8 \\
\cline { 2 - 3 } & more than 3 times per week & 23 \\
\hline \multirow{4}{*}{$\begin{array}{l}\text { No. of amal- } \\
\text { gam fillings }\end{array}$} & $0-5$ & 27 \\
\cline { 2 - 3 } & $6-10$ & 5 \\
\cline { 2 - 3 } & $11-15$ & 37 \\
\cline { 2 - 3 } & $16-20$ & 5 \\
\hline
\end{tabular}

\section{QA/QC}

All validation criteria used in analytical method have been published previously (31). The limit of detection for mercury was 0.7 ng. $\mathrm{g}^{-1}$, limit of quantification was $1.4 \mathrm{ng} . \mathrm{g}^{-1}$. Uncertainty was about $7 \%$ for $\mathrm{Hg}_{\text {in }}$ and $10 \%$ for $\mathrm{MeHg}$. The accuracy of the method was confirmed by the analysis of certified reference materials of hair: IAEA 85 (determined value for $\mathrm{MeHg} 22.4 \pm 2$ $\mu \mathrm{g} . \mathrm{g}^{-1}$, certified value $22.9 \mu \mathrm{g} . \mathrm{g}^{-1}, 95 \%$ C.I. 21.9-23.9 $\left.\mu \mathrm{g} . \mathrm{g}^{-1}\right)$; GBW 07601 (determined value for total $\mathrm{Hg} 0.38 \pm 0.04$, certified value $\left.0.36 \pm 0.05 \mu \mathrm{g} . \mathrm{g}^{-1}\right)$. The control sample analysed with every set of samples throughout the study was used to ensure the accuracy and compatibility of the results (see Shewhart's diagram on Fig. 1).

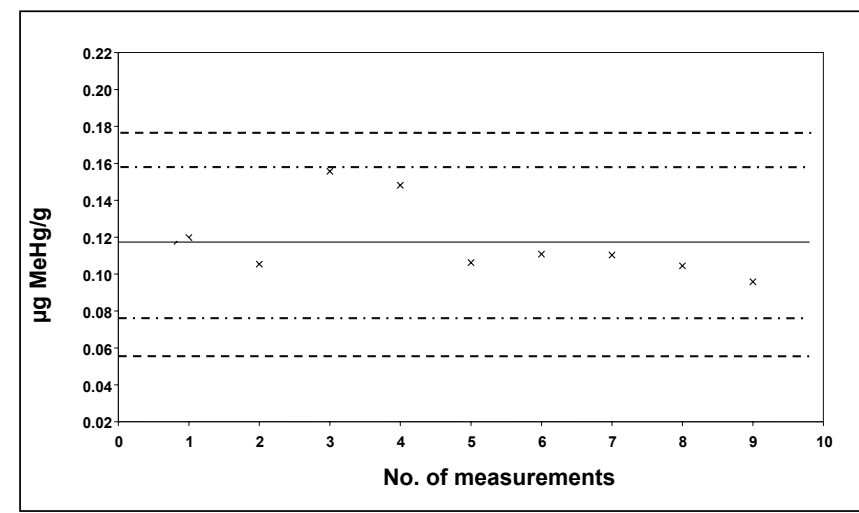

Fig. 1. Shewhard's regulation diagram for methylmercury dashed line: $\pm 3 S D$, dot and dashed line: $\pm 2 S D$, full line: mean. 


\section{Statistical Evaluation}

The results obtained for $\mathrm{MeHg}$ and $\mathrm{Hg}_{\text {in }}$ in the groups of dentists, workers in "freshwater" fish industry and professionally non-exposed adults (about 20 persons in each group) were statistically evaluated by ANOVA and QC Expert, and Student's t test at the level $\alpha \geq 0.95$ (39)

All results had log - normal distribution and therefore before statistical evaluation, the data were modified by logarithmic transformation. Calculated critical value of the determination coefficient $\left(\mathrm{R}^{2}\right)$ at the level $\alpha=0.95$ equals to 0.102 (higher values signalised significance of parameter).

In the evaluation, smoking habits were excluded because of the very low number of smokers ( $<10 \%$ from all participants).

The results on the hair concentration of mercury species are summarised in Table 2.

Table 2. Results of hair mercury species in groups of dentists and professional non-exposed population

\begin{tabular}{|l|c|c|c|}
\hline $\begin{array}{l}\text { Non-exposed } \\
\text { population groups }\end{array}$ & Hg total $\mu \mathrm{g} \cdot \mathrm{g}^{-1}$ & $\mathrm{MeHg} \mu \mathrm{g} \cdot \mathrm{g}^{-1}$ & $\mathrm{Hg}_{\text {in }} \mu \mathrm{g} \cdot \mathrm{g}^{-1}$ \\
\hline Median & 0.33 & 0.20 & 0.10 \\
\hline Max & 2.38 & 1.56 & 0.90 \\
\hline Min & 0.07 & 0.04 & $<0.01$ \\
\hline Percentile 0.9 & 1.00 & 0.72 & 0.26 \\
\hline & & & \\
\hline Dentists group & $\mathrm{Hg}$ total $\mu \mathrm{g} \cdot \mathrm{g}^{-1}$ & $\mathrm{MeHg} \mu \mathrm{g} \cdot \mathrm{g}^{-1}$ & $\mathrm{Hg}_{\mathrm{in}} \mu \mathrm{g} \cdot \mathrm{g}^{-1}$ \\
\hline Median & 0.51 & 0.29 & 0.23 \\
\hline Max & 5.69 & 1.60 & 4.45 \\
\hline Min & 0.28 & 0.07 & 0.11 \\
\hline Percentile 0.9 & 4.17 & 1.00 & 2.60 \\
\hline
\end{tabular}

\section{DISCUSSION}

Influences of various mutually independent parameters (age, number of amalgam fillings, dietary habits, professional exposure and gender) on methylmercury and inorganic bound mercury species were studied. Mercury species in human hair were determined in groups of dentists, workers in "freshwater" fish industry and professionally non-exposed adults with different dietary habits.

We found that differences among groups of workers in "freshwater" fish industry, other professionally non-exposed adults and celiatics (different dietary habits) in all parameters under study were statistically non-significant and these groups were henceforth taken as one "non-exposed" group. Dentists were treated as a professionally exposed group.

In all groups no significant influence of age and gender was found for both species.

A significant difference between non-exposed groups and dentists was found for inorganic mercury form. At dentists, the total mercury concentration $>1 \mu \mathrm{g} \cdot \mathrm{g}^{-1}$ (median $\mathrm{Hg}_{\text {tot }} 0.51 \mu \mathrm{g} \cdot \mathrm{g}^{-1}$ ) was found in 5 persons (i.e. $29 \%$ ) and median of abundance of $\mathrm{Hg}_{\text {in }}$ was about $60 \%$ while median of abundance of $\mathrm{Hg}_{\text {in }}$ in "non-exposed" group was about $30 \%$. Four dentists had the concentration of $\mathrm{Hg}_{\text {in }}>1 \mu \mathrm{g} \cdot \mathrm{g}^{-1}$. This fact can be explicated by the exogenous contamination of dentist's hair by inorganic form of mercury presented in the atmosphere of the working place. All non-dependent parameters seemed to be statistically non-significant in the group of dentists but differences could be covered up by the higher mercury content.

In the professionally non-exposed group we found that the median $\mathrm{Hg}_{\text {tot }}$ was $0.33 \mu \mathrm{g} \cdot \mathrm{g}^{-1}$, median of abundance of $\mathrm{MeHg}$ was $70 \%$. Two persons, having concentration of $\mathrm{MeHg}$ higher than $1 \mu \mathrm{g} \cdot \mathrm{g}^{-1}$ (1.5 and $1.2 \mu \mathrm{g} \cdot \mathrm{g}^{-1}$ resp.), consumed fish more than 3 times per week. Four persons have a concentration of $\mathrm{Hg}_{\mathrm{tot}}>1 \mu \mathrm{g} \cdot \mathrm{g}^{-1}$. The influence of amalgam fillings was non-significant for $\mathrm{MeHg}$ (determination coefficient 0.019) but significant for inorganic $\mathrm{Hg}$ (determination coefficient 0.193) (Fig. 2). The influence of fish consumption was significant for both $\mathrm{MeHg}$ (determination coefficient 0.533 ) and $\mathrm{Hg}_{\text {in }}$ (determination coefficient 0.189 ) (Figs. 3 and 4).

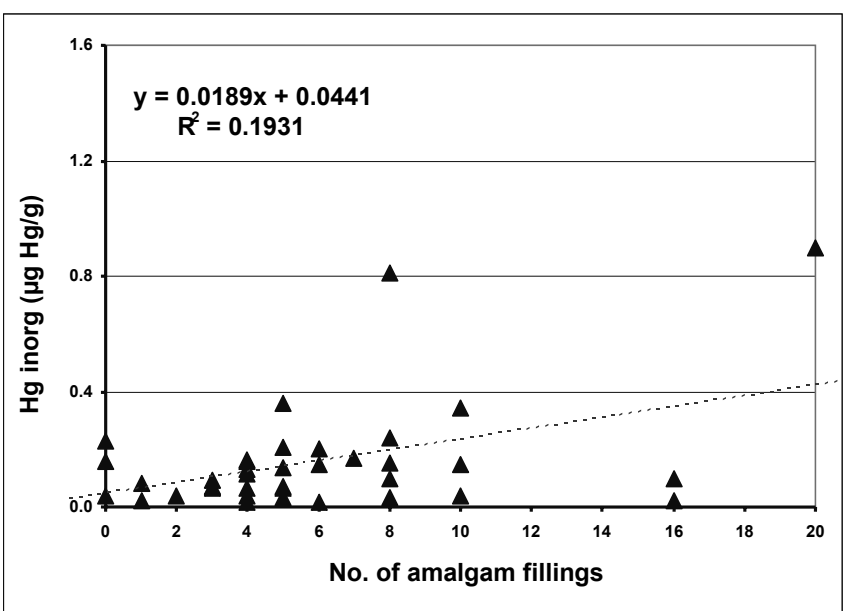

Fig. 2. Dependence of the inorganic bound mercury concentration in hair on the frequency of number of amalgam fillings (without group of dentists).

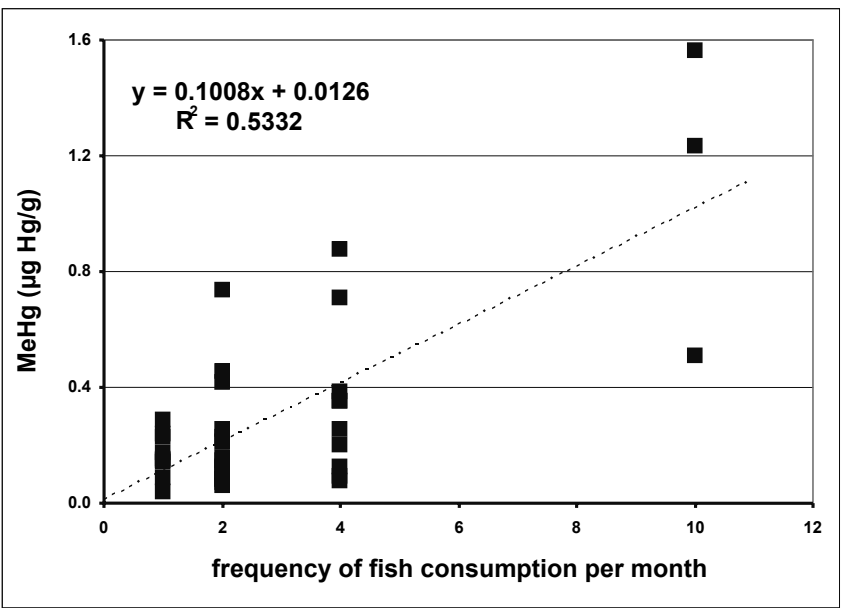

Fig. 3. Dependence of the methylmercury concentration in hair on the frequency of fish consumption (without group of dentists). 


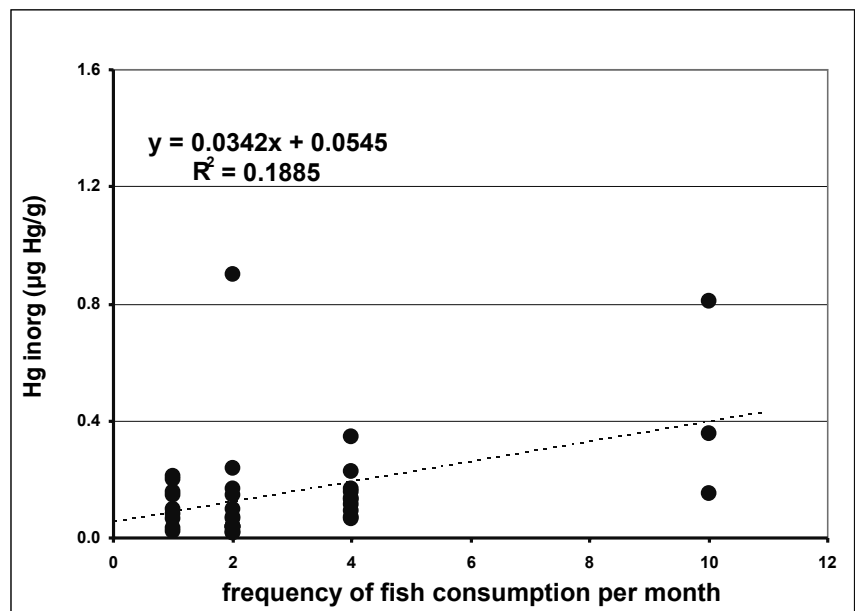

Fig. 4. Dependence of the inorganic bound mercury concentration in hair on the frequency of fish consumption (without group of dentists)

\section{CONCLUSION}

From the obtained results we can conclude that our results for non-exposed population are in agreement with non-exposed population in countries with similar dietary habits. The levels of mercury, obtained in the group of dentists, are also similar to the levels described in the literature, and represent both endogenous and exogenous exposure. The number of amalgam fillings was significant for $\mathrm{Hg}_{\text {in }}$; the significant influence of fish consumption on the $\mathrm{Hg}_{\text {in }}$ and especially on the $\mathrm{MeHg}$ levels was found although the consumption of fish in Czech Republic is rather low. The concentration levels found show that there is no serious problem with mercury exposure in Czech Republic.

The higher mercury level in dentist's hair can be ascribed to the work with amalgams and contaminated area of the surgery; the higher values in the "fish-eaters" were caused by $\mathrm{MeHg}$ (abundance of this form more than 70\%).

\section{Acknowledgement}

The work was supported by the IGA grant NR 8955-3/2006 and by the EU through its Sixth Framework Programme for RTD, PHIME (contracts no FOOD-CT-2006- 016253), The Institute of Analytical Chemistry of the ASCR, v.v.i., research project No AVOZ40310501

\section{REFERENCES}

1. Knobeloch L, Gliori G, Anderson H. Assessment of methylmercury exposure in Wisconsin. Environ Res. 2007 Feb;103(2):205-10.

2. International Programme on Chemical Safety. Mercury - environmental aspects. Environmental health criteria 86. Geneva: WHO; 1989.

3. International Programme on Chemical Safety. Methylmercury. Environmental health criteria 101. Geneva: WHO; 1990.

4. Horvat M, Gibičar D. Speciation of mercury, environment, food, clinical and occupational health. In: Cornelis R, Caruso J, Crews H, Heumann $\mathrm{KG}$, editors. Handbook of elemental speciation II. Chichester: Wiley and Sons; 2005. p. 281-304.

5. Tuček M. Present health risks of exposure to mercury and its compounds. Čes Prac Lék. 2006;7(1):26-37. (In Czech.)

6. Bencko V, Cikrt M, Lener J. Toxic metals in the living and working environment of man. Prague: Grada Publishing; 1995.

7. Knobeloch L, Anderson HA, Imm P, Peters D, Smith A. Fish consumption, advisory awareness, and hair mercury levels among women of childbearing age. Environ Res. 2005 Feb; 97(2):220-7.

8. Valentino L, Torregrossa MV, Saliba LJ. Health effects of mercury ingested through consumption of seafood. Water Sci Technol. 1995;32(9):41-7.

9. Elinder CG, Friberg L, Nordberg GF, Kjellstrom T, Oberdoerster G. Biological monitoring of metals. Chemical safety monographs. WHO/ EHG/94.2. Geneva: WHO; 1994.

10. Human Biomonitoring Commission of the German Federal Environment Agency. Hair analyses in environmental medicine. Bundesgesundheitsbl Gesundheitsforsch Gesundheitsschutz. 2005;48(2):246-50. (In German.)

11. Harkins DK, Susten AS. Hair analysis, exploring the state of the science. Environ Health Perspect. 2003 Apr;111(4):570-8.

12. Agency for Toxic Substances and Disease Registry [homepage on the Internet]. ToxFAQs [cited 2008 Aug 5]. Available from: http://www.atsdr. cdc.gov/toxfaq.html.

13. Chatt A, Katz SA. Hair analysis: applications in the biomedical and environmental sciences. New York: VCH Publishers; 1988.

14. Tobin DJ, editor. Hair in toxicology: an important Biomonitor. Cambridge: Royal Society of Chemistry; 2005.

15. Tuček M, Bencko V, Krýsl S. Health hazard of dental amalgams. Chem Listy. 2007 Dec;101(12):1038-44.

16. Dunn JE, Trachtenberg FL, Barregard L, Bellinger D, McKinlay S. Scalp hair and urine mercury content of children in the Norteast United States: the New England Children's Amalgam Trial. Environ Res. 2008 May;107(1):79-88.

17. Budtz-Jørgensen E, Grandjean P, Jørgensen PJ, Weihe P, Keiding N Association between mercury concentrations in blood and hair in methylmercury-exposed subjects at different ages. Environ Res. 2004 Jul;95(3):385-93. Erratum in: Environ Res. 2006 Oct;102(2):249.

18. Knobeloch L, Anderson HA, Imm P, Peters D, Smith A. Fish consumption, advisory awareness, and hair mercury levels among women of childbearing age. Environ Res. 2005 Feb; 97(2):220-7.

19. Valentino L, Torregrossa MV, Saliba LJ. Health effects of mercury ingested through consumption of seafood. Water Sci Technol. 1995;32(9):417.

20. Díez S, Montuori P, Pagano A, Sarnacchiaro P, Bayona JM, Triassi M. Hair mercury levels in an urban population from southern Italy: fish consumption as a determinant of exposure. Environ Int. 2008 Feb;34(2):162-7.

21. Björnberg KA, Vahter M, Grawé KP, Berglund M. Methyl mercury exposure in Swedish women with high fish consumption. Sci Total Environ. 2005 Apr 1;341(1-3):45-52.

22. Pesch A, Wilhelm M, Rostek U, Schmitz N, Weishoff-Houben M, Ranft $\mathrm{U}$, et al. Mercury concentrations in urine, scalp hair, and saliva in children from Germany. J Expo Anal Environ Epidemiol. 2002 Jul;12(4):252-8.

23. Lindberg A, Björnberg KA, Vahter M, Berglund M. Exposure to methylmercury in non-fish-eating people in Sweden. Environ Res. 2004 Sep;96(1):28-33.

24. Harakeh S, Sabra N, Kassak K, Doughan B. Factors influencing total mercury levels among Lebanese dentists. Sci Total Environ. 2002 Oct 7;297(1-3):153-60.

25. Montuori P, Jover E, Díez S, Ribas-Fitó N, Sunyer J, Triassi M, et al. Mercury speciation in the hair of pre-school children living near a chloralkali plant. Sci Total Environ. 2006 Oct 1;369(1-3):51-8.

26. Babi D, Vasjari M, Celo V, Koroveshi M.:Some results on $\mathrm{Hg}$ content in hair in different population in Albania. Sci Total Environ. 2000 Oct 2;259(1-3):55-60.

27. Kučera J, Bencko V, Sabbioni E, van der Venne MT. Review of trace elements in blood, serum and urine for the Czech and Slovak populations and critical evaluation of their possible use as reference values. Sci Total Environ. 1995 Apr 21;166:211-34.

28. Kučera J, Bencko V. Normal cocncentrations of trace elements in the Czech and Slovak populations for purposes of biomonitoring. Part II. $\mathrm{Hg}, \mathrm{Pb}, \mathrm{Rb}, \mathrm{Sc}, \mathrm{Se}, \mathrm{V}$ and $\mathrm{Zn}$ in blood, serum and urine. Prac Lék. 1997 May;49(2):79-92. (In Czech.)

29. Buchancová J, Knížková M, Hýllová D, Vrlík M, Meško D, Klimentová $\mathrm{G}$, et al. Content of the selected trace elements (Al, $\mathrm{As}, \mathrm{Cd}, \mathrm{Cu}, \mathrm{Fe}$, $\mathrm{Hg}, \mathrm{Mn}, \mathrm{Ni}, \mathrm{Pb}, \mathrm{Zn}$ ) in blood, urine and hair of blood donors without occupational exposure to these metals. Cent Eur J Public Health. 1994 Dec;2(2):82-7.

30. Obrusník I. Activation analysis of human hair as a tool for environmental pollution monitoring. J Hyg Epidemiol Microbiol Immunol. 1986;30(1):11-25.

31. Čejchanová M, Spěváčková V, Kratzer K, Wranová K, Spěváček V, Beneš B. Determination of mercury and methylmercury in hair of the Czech children's population.. Biol Trace Elem Res. 2008 Feb;121(2):97-105. 
32. Beneš B, Sladká J, Spěváčková V, Šmíd J. Determination of normal concentration levels of $\mathrm{Cd}, \mathrm{Cr}, \mathrm{Cu}, \mathrm{Hg}, \mathrm{Pb}, \mathrm{Se}$ and $\mathrm{Zn}$ in hair of the child population in the Czech Republic. Cent Eur J Public Health. 2003 Dec;11(4):184-6.

33. Čejchanová M, Spěváčková V, Kratzer K, Wranová K. Determination of mercury and methylmercury in the hair. In: Mikroelementy 2006. Český Těšín: 2 THETA; 2006. p. 41-5. (In Czech.)

34. Ewers U, Krause C, Schulz C, Wilhelm M. Reference values and human biological monitoring values for environmental toxins. Report on the work and recommendations of the Commission on Human Biologica Monitoring of the German Federal Environmental Agency. Int Arch Occup Environ Health. 1999 Jul;72(4):255-60.

35. National Institute of Public Health [homepage on the Internet]. Environmental Health [cited 2008 Aug 8]. Available from: http://www.szu. cz/topics/environmental-health.
36. Ruprich J. Consumer's foodstuff basket for the Czech Republic. Prague: National Institute of Public Health; 2000. (In Czech).

37. Kratzer K, Beneš P, Spěváčková V, Kolihová D, Žilková J. Determination of chemical forms of mercury in human hair by acid leaching and atomic absorption spectrometry. J Anal At Spectrom. 1994;9:303-6.

38. Spěváčková V, Korunová V, Čejchanová M, Vobecký M. Sampling procedure and a radio-indicator study of mercury determination in whole blood by using an AMA 254 atomic absorption spectrometer. Anal Bioanal Chem. 2004 Sep;380(2):346-50.

39. Meloun M, Militký J. Compendium of statistic data processing. Prague: Academia; 2002. (In Czech.)

Received August 5, 2008 Accepted in revised form November 10, 2008 